\title{
MODEL OF FUTURE TEACHERS' PROFESSIONAL TRAINING FOR TUTORING IN THE INFORMATION AND EDUCATIONAL ENVIRONMENT OF AN INSTITUTION OF HIGHER EDUCATION
}

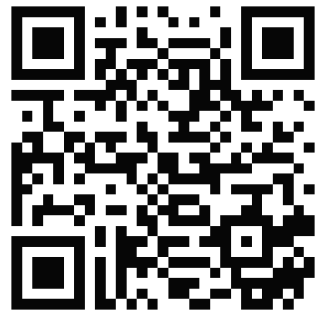

To cite this article:

\author{
Kateryna Osadcha, Dr. Sc., Ass. Prof. \\ Department of Computer Science and Cybernetics, \\ Bogdan Khmelnitsky Melitopol State Pedagogical University, \\ Melitopol, Ukraine \\ okp@mdpu.org.ua \\ https://orcid.org/0000-0003-0653-6423
}

Osadcha, K. (2020). Model of future teachers' professional training for tutoring in the information and educational environment of an institution of higher education.

Education: Modern Discourses, 3, 97-104.

https://doi.org/10.37472/2617-3107-2020-3-09

\begin{abstract}
The article is based on a review of scientific and methodological literature, it analyzes the existing models of future teachers' professional training for tutoring. The aim of the article is to design a model of future teachers' professional training for tutoring in the information and educational environment of the institution of higher education. As a result of scientific analysis, carried out on the basis of a systematic approach, theory and practice of tutoring, training for tutoring in Ukraine and abroad, the components of training for tutoring have been identified (target, philosophical, theoretical-methodological, informative-processual, criteria-evaluative, resultative). Each component of the designed model has its implementation in the information and educational environment. This model is a set of information and communication technologies (distance learning technologies, general purpose ICT and ICT for tutoring support), which are integrated into the educational process.
\end{abstract}

Key words: higher education; information and educational environment; future teacher; modeling; model; professional training; tutoring activities.

\section{INTRODUCTION. PROBLEM STATEMENT}

In a rapidly changing society scientists often raise the issue of correlation of future teachers' training with the realities of professional activity, needs of society and labor market. In this regard, researchers (I. Prokopenko, A. Kirichok, V. Tikhonovych) study different roles of a teacher in modern society: coach, mentor, tutor, facilitator, advisor. In the theory and practice of higher education there appear new approaches to future teachers' professional training for various roles in their future pedagogical activities. A significant achievement in this field is the understanding of the teacher's tutoring position and teacher's training for tutoring. So, as stated in the Concept of the New Ukrainian School, now it is worth talking about the role of a teacher not as a single mentor and source of knowledge, but as a coach, facilitator, tutor, moderator of the child's individual educational trajectory. 
Therefore, students of pedagogical specialties of the institutions of higher education have to be trained for tutoring. Thus, the structure of the subject under study, system of factors, which influence it, and internal links must be clearly identified. Therefore, it is necessary to model the future teachers' professional training for tutoring. Taking into account the importance of information and communication technologies in modern society (V. Osadchyi, V. Kruglyk) and the fact that they are often used in tutoring (S. Sysoieva, V. Kukharenko), it is advisable to model this process in the information and educational environment of the institution of higher education.

\section{LITERATURE REVIEW}

Modern researchers define a model as a representative system, its analysis serves as a way to obtain information about another system (Kulchytskyi, 2015). In general, a model in pedagogical research reflects a system of elements which reproduce the sides, relationships, functions, conditions of pedagogical process functioning. A well-designed model has a very attractive feature: its research gives some new knowledge about the object. This is an idealized notion of the correspondence to a real object of study (Duranov et al., 1996). Modeling is one of the main methods of scientific research. Therefore, scientists have proposed some author's models, in particular: model of human sciences teachers' step-by-step training for the performance of tutoring functions in the distance learning system (Koycheva, 2004); model of realization of technology of University students' readiness for tutoring (Ivashchenko, 2011); model of development of future lecturers' value-semantic readiness for tutoring (Suchanu, 2016).

Based on the analysis of the scientific literature, we identified models that reflect certain aspects of future teachers' training for tutoring: model of future teacher' training for the organization of subject-subject interaction with primary school students (Linnik, 2016); pedagogical technology of future teachers' training for the individualization of students' learning (Yeremeyeva, 2002); structural-procedural model of future teachers' training for learner-centered education of primary schoolchildren (Gumennikova, 2011).

Based on the analysis of these models, it was concluded that they do not meet the requirements for the improvement of future teachers' training for tutoring. Therefore, the aim of our research is to design a model of future teachers' professional training for tutoring in the information and educational environment of the institution of higher education.

\section{METHODOLOGY}

In order to conduct the research a method of content analyses was used. The review of the Ukrainian and English scientific literature (monographs and articles) was done in order to understand and structure the issues, related to the topic under the research. The modeling method was used to reflect the system of elements, as this system reproduces their connections, functions, organizational and methodological conditions of the process of future teachers' professional training for tutoring.

\section{MAIN RESULTS}

In the process of modeling the future teachers' professional training for tutoring, we were based on the understanding that modeling should be focused on the content of the tutor's professional activity. It has been identified in previous studies (Osadcha, 2017a; Osadcha, 2017b; Osadcha, 2016).

Modeling of future teachers' professional training for tutoring is necessary in order 
to: manage this process according to certain organizational and methodological principles, goals and criteria; anticipate direct and indirect consequences of realization of the given ways and forms of impact on the subject of pedagogical interaction (future teachers) with the achievement of desirable outcomes (development of future teachers' tutoring competence); provide processability of future teachers' tutoring competence development.

Based on the principles of a systematic approach (Yudin, 1997), research on the theory and practice of tutoring and training for tutoring in Ukraine (Ivashchenko, 2011; Sysoieva et al., 2011) and abroad (Gordon et al., 2007; Koskinen \& Wilson, 1982; Riffort, 2007), implementation of the Concept of future teachers' professional training for tutoring in the information and educational environment (Osadcha, 2019), we have identified components of future teachers' professional training for tutoring: target; philosophical; theoreticalmethodological; informative-processual; criterial-evaluative; resultative. These components laid the foundation for the design of a model of future teachers' professional training for tutoring in the information and educational environment of the institution of higher education (Fig. 1). Each component of the designed model of future teachers' professional training for tutoring has its implementation in the information and educational environment (IEE).

Target component of the model of future teachers' professional training for tutoring in the institution of higher education determines a need of society for the individualization of the educational process; aim, which presupposes the improvement of future teachers' professional training for tutoring; requirements for a modern teacher as a specialist in the individualization of education. IEE tools allow researchers to monitor the requests of employers and society for teachers with tutoring competence, as well as requirements for the qualification of tutors in different types of educational institutions (secondary, out-of-school, family, etc.).

This is done through such type of web resource as an online database of vacancies. Also on the basis of educational web resources (educational information sites, online media, blogs, social networks) the current trends in Ukrainian and foreign education, aimed at the individualization of education in order to actualize the aim of future teachers' training for tutoring, are studied and generalized.

Theoretical-methodological component reveals a terminological apparatus of the research of future teachers' professional training for tutoring, methodological approaches (anthropological, culturological, systematic, activistic, synergetic, phenomenological, praxeological), pedagogical laws and principles of future teachers' professional training for tutoring and structure of tutoring competence. Teacher's tutoring competence consists of the following components: suggestive, psychological, pedagogical, organizational, informationaltechnological, communicative, methodological, perceptive and scientific-research. In order to reveal the theoretical and methodological principles of tutoring, it will be important for the future teachers to use the following IEE tools: online reference books, encyclopedias, dictionaries, textbooks, manuals, repositories of scientific publications, proceedings of scientific conferences.

Informative-processual component includes organizational and methodological principles of future teachers' professional training for tutoring, which reflect the content of training and are developed on the basis of the standard of Bachelor's and Master's degrees in educational field, author's proposals, classroom and extracurricular forms of teaching, general didactic and innovative teaching methods, traditional and specific technologies and teaching aids. This component also covers the process of subject-subject interaction of the participants of educational process. Information and communication technologies, that are a part of the structure of the information and educational environment, are used for interaction between the subjects of the educational process. So we can talk about three subjects of didactics, where the subjects are the teacher, the student and the IEE. This component is realized through a use 
of a wide range of ICT, which are included into the IEE of future teachers' professional training for tutoring.

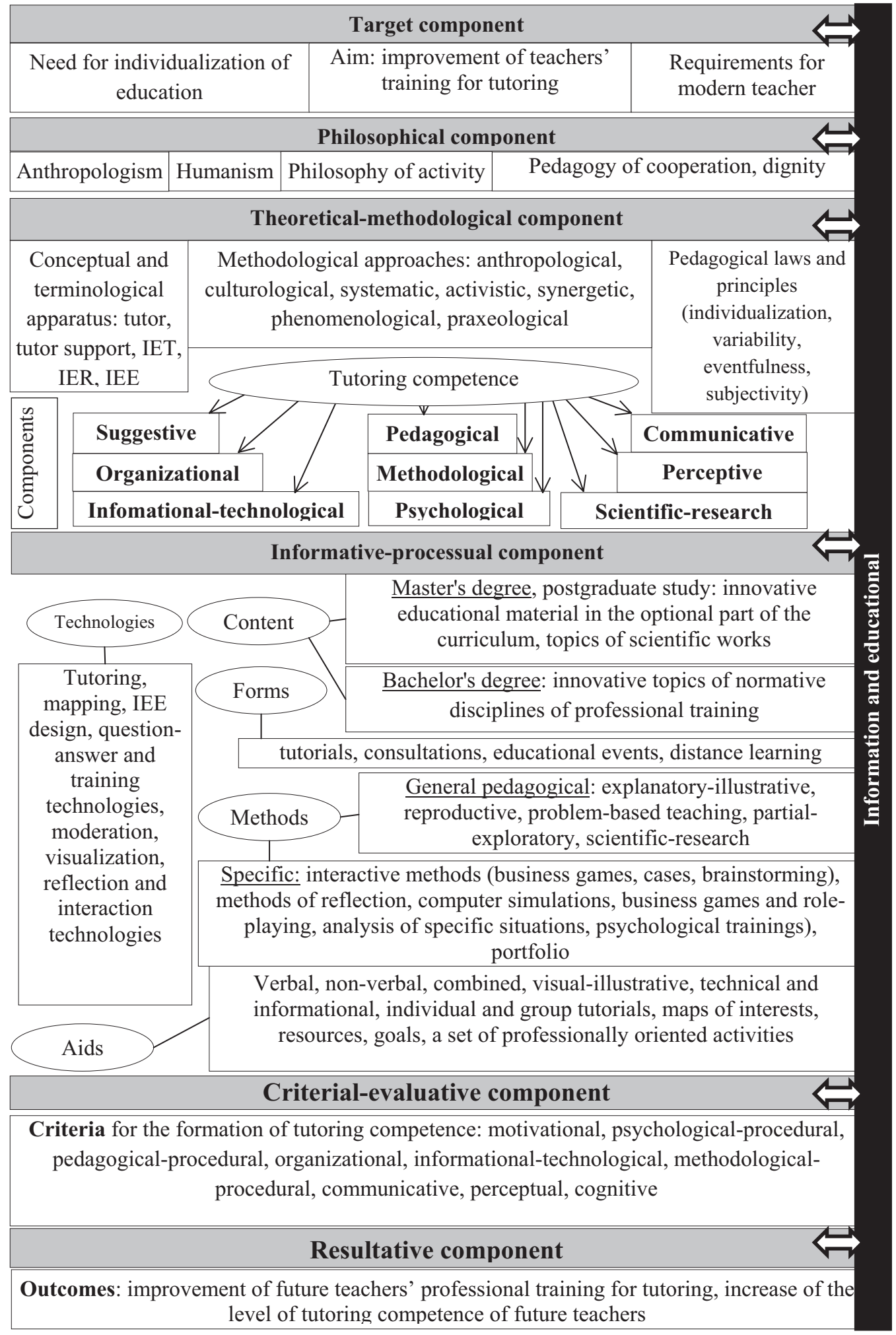

Fig. 1.

Model of future teachers' professional training for tutoring 
The main tools are distance learning technologies (including adaptive ones) and the following ICT: general purpose technologies (technologies for presenting educational information; technologies for storing and processing educational information; technologies for transmitting educational information; technologies for interaction between subjects of educational process; technologies for monitoring and evaluation of students' educational achievements and tutoring support. ICT of tutoring support include the information and communication tools in accordance with the stages of tutoring, namely: technologies for the identification of cognitive interest (testing programs or online tests); technologies for the formulation of an educational request (online boards, online intelligence cards); technologies for setting the aim of educational activity as a way to achieve the expected outcomes (planners, organizers, calendars); technologies for searching for educational resources and developing a plan of educational activity (search engines, information aggregators, deferred reading services, image storage and exchange services, services for creating educational materials); technologies for implementation, discussion, analysis and adjustment of the plan of educational activity (office programs, portfolio creation services); technologies for the analysis of the educational activity outcomes (testing programs or services, programs for creating educational materials, online resources for psychological tests); technologies for adjusting educational goals, identifying temporary perspectives (electronic presentations, spreadsheets) (Fig. 2).

Criterial-evaluative component of the model of future teachers' professional training for tutoring covers the criteria of tutoring competence development, which serves as a basis for the identification of the level of future teachers' professional training for tutoring - high, medium, low. The following requirements were taken into account while developing the criteria and indicators for the level of tutoring competence formation: correspondence of criteria and their indicators to the components of tutoring activities; determination and interrelation of criteria as the features of a system, which are used to assess the level of development of all components of tutoring competence (suggestive, psychological, pedagogical, organizational, informational-technological, methodological, communicative, perceptive, scientific-research); adaptability of the criterion apparatus to the process of future teachers' professional training in the institution of higher education.

According to the structure of tutoring activity in the criterial-evaluative block the following criteria of formation of tutoring competence are offered: motivational, psychologicalprocedural, pedagogical-procedural, organizational, informational-technological, methodological-procedural, communicative, perceptual, cognitive. Thus, the criterion basis for the effectiveness of future teachers' professional training for tutoring consists of eight criteria. Each of them is aimed at the assessment of the level of formation of future teachers' personal knowledge and skills in tutoring; ability to carry out tutoring activities in secondary schools and in the non-formal educational establishments (home, distance, external, etc.); worldview attitude to tutoring activities and focus on continuous improvement of teachers' tutoring competence.

Let's identify the content of each criterion and its indicators.

1. Motivational criterion characterizes the level of formation of future teacher's motivation to develop tutoring competence in the process of professional training, to acquire professional knowledge and develop skills necessary for the formulation of goals, motives, shaping interests, spiritual needs of the children in educational activities; this criterion also identifies the degree of formation of future teacher's emotional and volitional qualities, which are important for tutoring.

2. Psychological-procedural criterion allows to assess the level of formation of psychological knowledge (human psychology, age psychology, methods of self-regulation and self-management, psychological and pedagogical diagnosis of personality) and the ability to individualize the educational process, based on the implementation of individual and learner- 
centered approaches, IOT study, IOP and IOR development. Pedagogical-procedural criterion is characterized by the level of formation of pedagogical knowledge, ability to use pedagogical methods, forms, tools and technologies for the development and support of learner's individual educational program.

3. Organizational criterion determines the level of formation of future teachers' organizational skills, which are necessary for tutoring activities. In the process of implementation of the model of future teachers' professional training for tutoring informationaltechnological criterion allows to assess the level of formation of information literacy and the degree of formation of skills, which are necessary to carry out tutoring activity with the use of information and communication technologies.

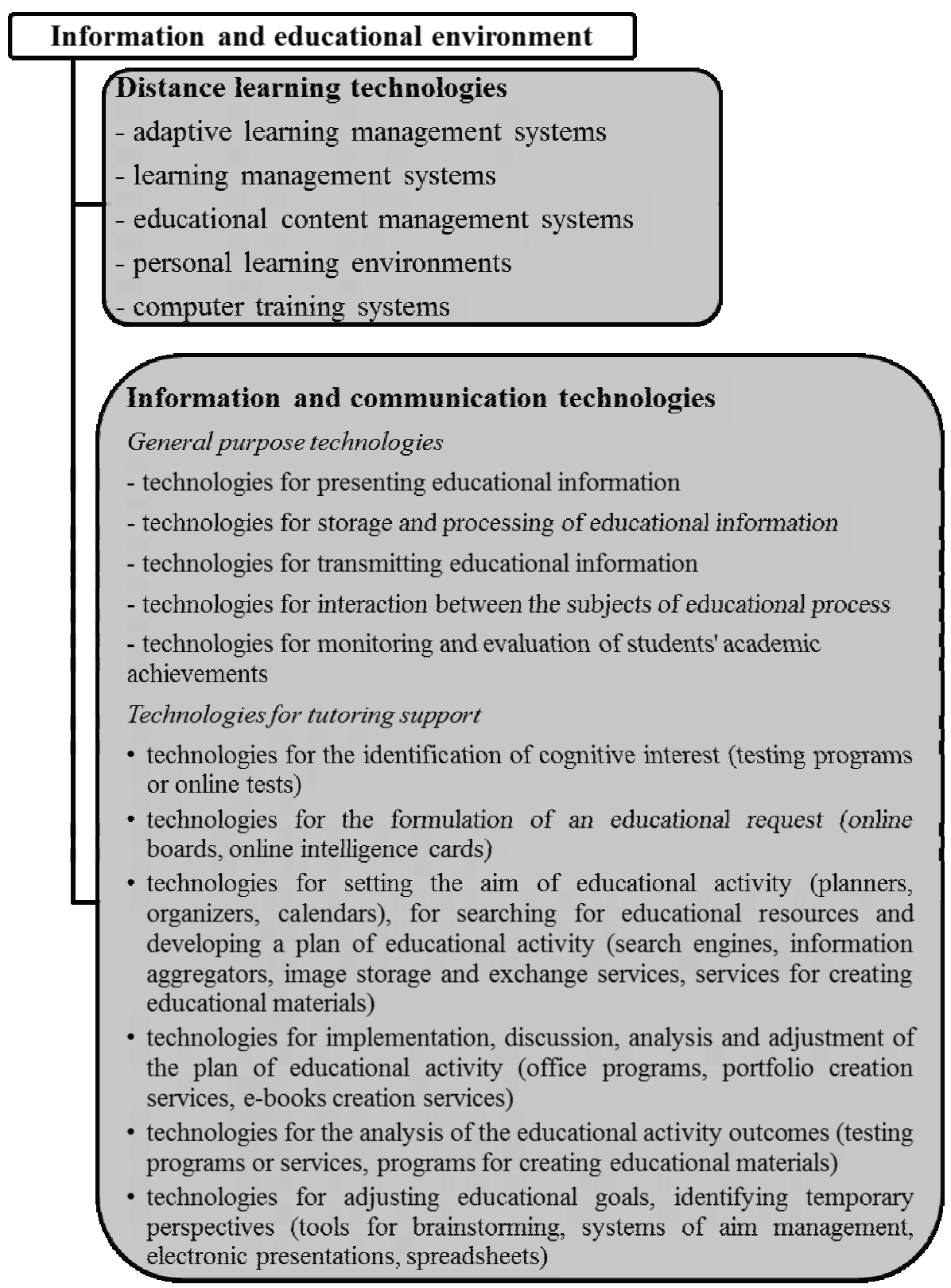

Fig. 2.

The structure of the information and educational environment of future teachers' professional training for tutoring 
4. Methodological-procedural criterion characterizes the level of formation of methodological knowledge and ability to effectively and qualitatively solve methodological problems in a wide range of pedagogical situations in the context of a subject taught.

5. Communicative criterion involves the assessment of the level of future teachers' proficiency in using the technique of pedagogical communication and communicative abilities in the process of their professional training for tutoring.

6. Perceptive criterion is characterized by the level of formation of student's value attitude to tutoring and the level of formation of professional knowledge and skills, which are necessary to manage the process of children's emotional development and emotional regulation.

7. Cognitive criterion allows researchers to assess the level of future teachers' cognitive level of research skills development in the process of their professional training for tutoring.

The integration of the criterial-evaluative component with IEE takes place at the level of using ICT for monitoring, evaluation and assessment of program learning outcomes provided by the curriculum of the specialty 014.09 "Secondary education (by subject specializations)". These are built-in tools for testing, surveying and monitoring of competencies in the distance learning system and various Internet tools (online testing quizzes interactive means of assessment, task setting and control systems, etc.).

Resultative component of the model of future teachers' professional training for tutoring determines the improvement of future teachers' professional training for tutoring (increase in the level of tutoring competence). Most of the outcomes of future teachers' professional training for tutoring are reflected in electronic form, in particular, in the journal of distance learning site, electronic journals, electronic tools of educational achievements presentation (e-portfolio, electronic presentations, infographics, etc.).

\section{CONCLUSIONS}

The designed model of future teachers' professional training for tutoring in the information and educational environment of the institution of higher education is a dynamic structure that can be supplemented and updated in accordance with changing requirements of society and economy. The model of future teachers' professional training for tutoring in the information and educational environment of the institution of higher education organically combines following components: target, philosophical, theoretical-methodological, informativeprocessual, criterial-evaluative, and resultative. They are of special importance due to their content, which allows researchers to take into account the specifics of future teacher's role of a tutor while performing professional activity.

\section{REFERENCES}

Duranov, I. M. Duranov, M.E.. Lesher, O.V. \& Zhernov, V.I. (1996). Pedagogika vospitaniya $i$ razvitiya lichnosti uchashchikhsya [Pedagogy of education and personality development of students]. Magnitogorsk: MGPI. (in Russian)

Gordon, E. E., Morgan, R. R., O’Malley, C. J. \& Ponticell, J. (2006). The Tutoring Revolution: Applying Research for Best Practices, Policy Implications, and Student Achievement. Lanham, MD: R\&L Education

Gumennikova, T. R. (2011). Teoretyko-metodychni zasady pidhotovky pedahoha do osobystisno oriientovanoho vykhovannia molodshykh shkoliariv $v$ umovakh stupenevoi osvity : avtoref. dys.... dokt. ped. nauk: 13.00.04 [Theoretiko-methodological basis of the future teacher's preparation to the personal oriented education of younger schoolchildren in the conditions of step education] (Extended abstract of Doctor's thesis). Kyiv. (in Ukrainian)

Ivashchenko, M.V. (2011). Formuvannia hotovnosti studentiv vyshchykh pedahohichnykh navchalnykh zakladiv do diialnosti tiutora : avtoref. dys. ... kand. ped. nauk : 13.00 .04 
[Forming Readiness of Students to Tutor's Activity in Higher Pedagogical Educational Institutions] (Extended abstract of Doctor's thesis). Kharkiv. (in Ukrainian)

Koskinen, P. S. \& Wilson, R. M. (1982). Tutoring, a guide for success. New York: Teachers College Press, Teachers College, Columbia University

Koycheva, T.I. (2004). Pidhotovka maibutnikh uchyteliv humanitarnykh spetsialnostei yak tiutoriv dlia systemy dystantsiinoi osvity: avtoref. dys... kand. ped. nauk: 13.00.04 [Preparation of future humanities teachers as tutors of distance learning systems] (Extended abstract of Doctor's thesis). Odessa. (in Ukrainian)

Kulchytskyi, I. M. (2015). Kontseptualizatsiia poniat "model" ta "modeliuvannia" u naukovykh doslidzhenniakh [Conceptualization of the concepts "model" and "modeling" in scientific research]. Journal of Lviv Polytechnic National University "Information Systems and Networks", (829), 273-284. (in Ukrainian)

Linnik, O. O. (2016). Systema pidhotovky maibutnoho vchytelia do subiekt-subiektnoi vzaiemodii $z$ uchniamy pochatkovoi shkoly : dys. ... dokt. ped. nauk : 13.00.04 [System of future teacher's training to organize the subject-subject interaction with primary school pupils] (PhD Thesis). Starobilsk. (in Ukrainian)

Osadcha, K., Osadchyi, V., \& Kruglyk, V. (2020). The role of information and communication technologies in epidemics: an attempt at analysis. Ukrainian Journal of Educational Studies and Information Technology, 8 (1), 62-82. https://doi.org/10.32919/uesit.2020.01.06 (in Ukrainian)

Osadcha, K. P. (2016). Osoblyvosti orhanizatsii tiutorskoho suprovodu pidlitkiv [Special aspects organization of tutor support for secondary school students]. Problems of engineer-pedagogical education, 52-53, 211-216. (in Ukrainian)

Osadcha, K. P. (2017a). Spetsyfika orhanizatsii tiutorskoho suprovodu uchniv starshoi shkoly [Specific features of tutor support for high school students]. Scientific Bulletin Melitopol State Pedagogical University. Series: Pedagogy, 1, 177-182. (in Ukrainian)

Osadcha, K.P. (2017b). Spetsyfika orhanizatsii tiutorskoho suprovodu uchniv pochatkovoi shkoly [The specific of organization of the tutor's support of students of primary school]. Youth \& market, 5 (148), 63-69. (in Ukrainian)

Osadcha, K.P. (2019). Kontseptualni zasady pidhotovky maibutnikh uchyteliv do tiutorskoi diialnosti [The concept of training teachers for the tutoring activity]. Scientific journal "Transactions of Kremenchuk Mykhailo Ostrohradskyi National University", 3, 25-32. (in Ukrainian)

Osadchyi, V. (2019). Modern information and communication technologies for the professional training of future teachers. Education: Modern Discourses, 2, 171-177. https://doi. org/10.32405/2617-3107-2019-1-20. (in Ukrainian)

Riffort, S. (2007). Tutor training: Facilitation of transition through technology. (Doctoral Dissertation). Dublin: University of Dublin

Suchanu, A. K. (2016). Formuvannia tsinnisno-smyslovoi hotovnosti do tiutorskoi diialnosti u mahistriv humanitarnykh spetsialnostei : dys... kand. ped. nauk : 13.00.04 [Formation of value-semantic readiness for tutoring in masters of humanities] ( $\mathrm{PhD}$ Thesis). Kirovohrad. (in Ukrainian)

Sysoieva, S. O., Osadchyi, V. V. \& Osadcha, K. P. (2011). Profesiina pidhotovka vykladachatiutora: teoriia i metodyka [Professional training of a tutor: theory and methodology]. Kyiv-Melitopol : "Vydavnychyi budynok MMD”. (in Ukrainian)

Yeremeyeva, V. M. (2002). Pedahohichna tekhnolohiia pidhotovky maibutnikh uchyteliv do indyvidualizatsii navchannia uchniv : avtoref. dys... kand. ped. nauk 13.00 .04 [Pedagogical technology of teacher training for individualization of teaching pupils] (Extended abstract of Doctor's thesis). Kyiv. (in Ukrainian)

Yudin. E. G. (1997). Metodologiya nauki. Sistemnost. Deyatelnost [Methodology of Science. Consistency. Activity]. Moskva: Editorial URSS. (in Russian) 